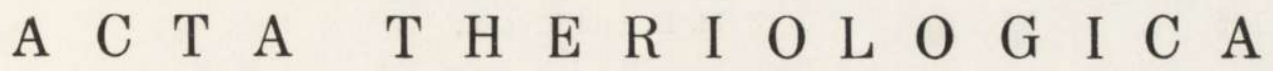

VOL. XVI, 8: 105-125

BIAŁOWIEŻA

August, 1971

Michael H. S M I T H, Roland B L E S S I N G, John G. C H E L T O N, *

John B. GEN T R Y, Frank B. G O L L EY \& John T. Mc G IN N IS

\section{Determining Density for Small Mammal Populations Using a Grid and Assessment Lines**}

[With 2 Tables \& 9 Figs.]

\begin{abstract}
A modification of the Polish Standard Minimum $16 \times 16$ grid was used to obtain density estimates. Eight assessment lines were used to evaluate the area of effect around the grid. Mammals were removed out to $98 \mathrm{~m}$ from the grid. Theoretical considerations for the density calculations using data from the assessment lines are given along with an example. Density as calculated by the method recommended in the Polish Standard Minimum method was $81 \%$ higher than the comparable figure (15.99 small mammals per ha) calculated by the assessment line method. The discrepancy results from the movement of mammals onto the plot during the removal phase of the study. The number removed was equivalent to the resident population of small mammals on the grid in only 2.8 days of trapping. Future studies must evaluate the area of effect around the grid; the assessment line method is the only known way of efficiently estimating the size of the border zone.
\end{abstract}

\section{INTRODUCTION}

We are in the process of evaluating a number of different techniques to estimate the absolute density of small mammal populations ( $\mathrm{G}$ e $\mathrm{n} \mathrm{r} \mathrm{y}$, Golley \& Smith, 1968; Smith, Gentry \& Golley, 1970; Gentry, Smith \& Beyers, 1971b; Gentry, Smith \& Chelton, 1971c; Kaufman, et al., 1971). The importance of reliable density estimates can hardly be overestimated, since they are used for calculations in studies of bioenergetics, mineral cycling, and population ecology and in studies of mammals as disease vectors.

Mathematical techniques for estimating population size are well developed (see Hanson, 1967 for a review), but two assumptions are

* Mr. J. Chelt on was killed in an automobile accident before the completion of this paper.

** This study was carried out under contract AT(38-1)-310 between the Atomic Energy Commission and the University of Georgia. 
usually made that are incorrect. First, the probability of capture is not constant for all animals (e. g., $\mathrm{T}$ an to n, 1965 \& 1969; $\mathrm{S} \mathrm{m}$ ith, 1968) or at different times during the sampling interval (Calhoun, 1963; Gentry et al., 1968, 1971 a, b, \& c; Kaufman et al., 1971). Secondly, the population at risk of capture does not stay constant but increases through the sampling interval due to immigration. It may be possible in certain cases to mathematically compensate for these biases (Tanaka \& Kanamori, 1967; Janion, Ryszkowski \& Wierzbowska, 1968). However, this only avoids the primary criticism of existing methods; density $(D)$ is number $(N)$ per unit area $(A)$ or volume $(V)$ and existing techniques focus almost exclusively on $N$ while completely ignoring $A$ or $V$.

Two practical ideas have been put forth to estimate $A$. The first involves marking the bait during a prebaiting period to determine the area in which captured animals were feeding prior to the beginnig of removal (A damczyk \& Ryszkowski, 1968; Gentry et al., $1971 \mathrm{~b})$. The second method involves the use of assessment lines (e. g., Wheeler \& Calhoun, 1968). These lines extend from the census area into the border zone and are used to estimate the area actually sampled by the census grid or line. There should be some ambient rate (number per unit of linear distance) of catching animals along the assessment line. This rate should be a partial function of denstiy, which in turn is determined in the border zone around the census grid or line by the effect of trapping on the census grid or line. The distances at which the rates of capture change will indicate the extent of the area of effect around the grid or line.

Our primary purpose in paper is to describe a modification of the Standard Minimum Method (Grodziński, Pucek, \& Ryszkow$\mathrm{ski}$ i, 1966) utilizing assesment lines. The theoretical basis for the density calculations and an illustration using actual data collected on the Savannah River Project are also given. Our specific purpose was to quantitatively assess the area of effect around the grid and to use this area estimate to calculate density.

\section{METHODS}

A 5.06 ha grid, consisting of 256 stations $(16 \times 16)$ spaced $15 \mathrm{~m}$ apart was laid out in a lowland mesic-hardwood forest (see Gentry et al., 1968 for description of habitat). One Museum Special and one Victor mouse snap-trap were placed at each station. Traps were prebaited with peanut butter for five days. On the sixth day the traps were set and checked, and were rebaited and reset as necessary each day thereafter. Location of capture, sex, reproductive condition, weight and species identification of each animal were recorded. Trapping started on August 15, 
1968 and was continued on consecutive days for the length of this part of the study

On the nineteenth day of trapping, traps were set on 8 assesment lines extending from a distance of $60 \mathrm{~m}$ inside the grid to $120 \mathrm{~m}$ from the grid. Each line was perpendicular to one side of the grid and located $52.5 \mathrm{~m}$ from a corner of the grid. Trap stations were located $7.5 \mathrm{~m}$ apart on the assesment lines, and the traps were arranged the same way as on the grid but not prebaited. Traps were checked for 22 consecutive days on the assesment lines.

The basic idea is to create an area of effect by removing mammals with a census line or grid as in our study. Onefor more assessment lines are then used to measure the size of this area and the extent to which mammals have been removed from it.

Accumulating captures along a trap line results in a straight line (G e ntry et al., 1971c; Ka u fma n et al., 1971) which can be calculated by the least squares method ( $\mathrm{S}$ teel \& Torrie, 1960). The slope $(b)$ of this line represents the ambient rate of capture per unit distance for a given number of trapping nights; $b$ is dependent upon the density of small mammals and environmental factors responsible for varying the probability of capture $P_{c}$ during the trapping period. If all of the mammals have been removed from the sampling area, $b$ will abruptly change at the edge of the sampling area and will equal 0 inside this area (see Fig. 1). The exact point of change in $b$ can be calculated by the simultaneous solution of the two equations for the straight lines,

$$
\begin{aligned}
& \mathrm{Y}=a_{c}+b_{c} X \\
& \mathrm{Y}=a_{u}+b_{u} X .
\end{aligned}
$$

$Y$ is equal to the accumulative number of captures, $X$ is distance in meters, $a$ is the intercept of the line, and $b$ is as defined before (Fig. 1). The subscripts refer to the area of complete removal (c) and the unaffected area $(u)$. The point $\left(X_{c}\right)$ along the assessment lines representing the edge of the area of complete removal $\left(A_{c}\right)$ can be calculated by

$$
X_{c}=\frac{a_{c}-a_{u}}{b_{u}-b_{c}}
$$

The width in meters $\left(W_{c}\right)$ of $A_{c}$ outside the grid is

$$
W_{c}=L_{a}-X_{c}
$$

$L_{a}$ is the length of the assessment lines outside the grid or $120 \mathrm{~m}$ for the $16 \times 16$ grid. If the captures were accumulated with the end of the assessment lines farthest from the grid as the starting point, then the size of the sampling area

$$
A_{\mathrm{c}}=\left(2 W_{\mathrm{c}}+\mathrm{W}_{g}\right)^{2}
$$


with $W_{g}$ equal to the length of the side of the grid or $225 \mathrm{~m}$ for the $16 \times 16$ grid. Dividing the actual number of mammals caught on the grid $\left(N_{a}\right)$ by $A_{c}$ yields density $(D)$.

In addition to $A_{c}$, there is usually an area of partial removal $\left(A_{p}\right.$; Fig. 1). The width $\left(W_{p}\right)$ of $A_{p}$ can be calculated in a manner similar to that in which $\mathrm{W}_{\mathrm{c}}$ was calculated. An equivalent area of complete removal $\left(A_{c p}\right)$ must be calculated for $A_{p}$. The number of animals $\left(N_{u}\right)$ that would have been captured on the assessment lines if there had not been an area of partial removal is equal to $Y_{u}$, and

$$
Y_{u}=a_{u}+b_{u} \boldsymbol{X}_{c} .
$$

The number actually caught up to the edge of the area of complete removal $\left(N_{p}\right)$ can be calculated by

$$
Y_{p}=a_{p}+b_{p} X_{c} ; N_{p}=Y_{p}
$$

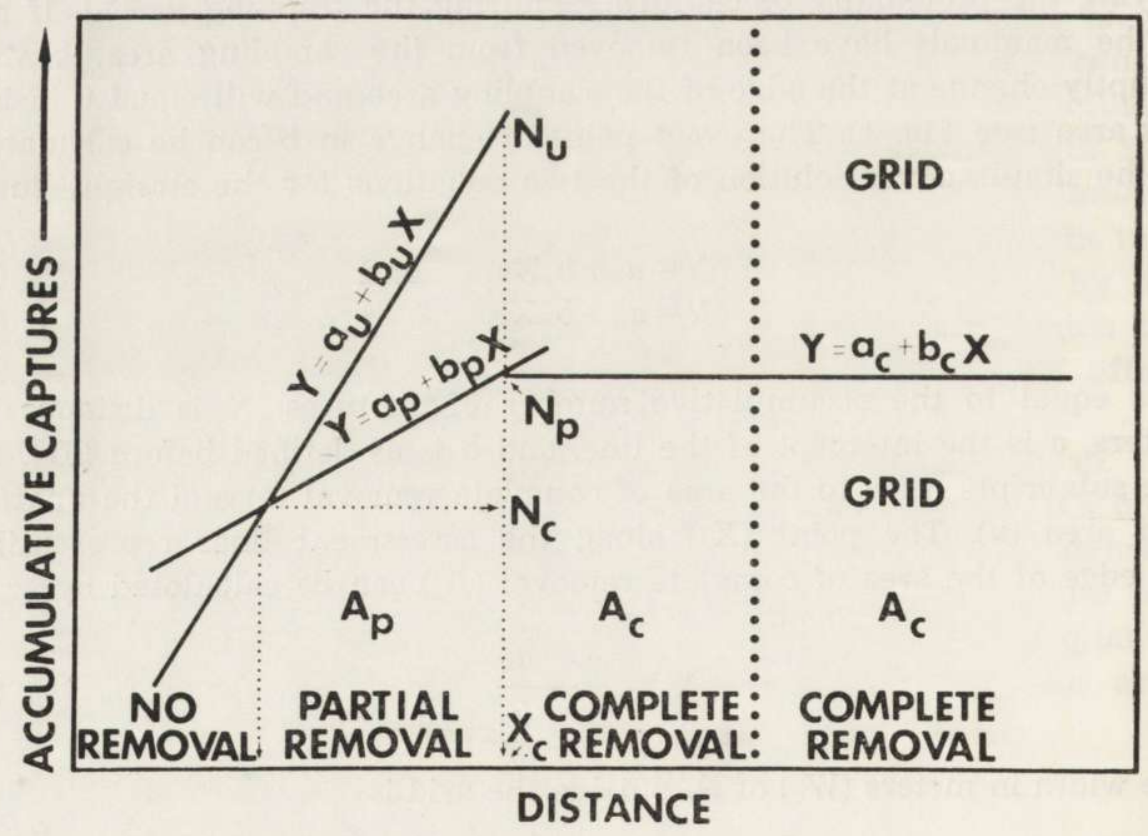

Fig. 1. Linear relationships between accumulative captures on the assessment lines as a function of distance from the outer ends of the assessment lines to the ends inside the grid. $X_{c}$ denotes the edge of the area $\left(A_{c}\right)$ from which all mammals had been removed. $A_{p}$ equals the area of partial removal. $N_{u}$ equals the number of animals that would have been caught along the assessment lines up to $X_{c}$ if $A_{p}$ were equal to $0 . N_{p}$ equals the accumulative number of animals actually caught at $X_{c} . N_{c}$ equals the number of animals that would have been caught if $A_{c}$ had included the entire area of $A_{p}$. 
at this point. $N_{c}$ is equal to the number of animals that would have been caught on the assessment lines if the area of complete removal had extended up to the edge of the area of partial removal.

$$
A_{c p}=\frac{N_{u}-N_{p}}{N_{u}-N_{c}} \cdot A_{p}
$$

In other words, $A_{c p}$ equals the ratio of animals that should have been caught on the assessment lines if there had been no area of partial effect to those actually caught in this area times the size the area of partial effect. This assumes $\bar{P}_{c}$ is equal for animals of the same species in the unaffected area and in $A_{p}$. Interspecific individual or daily variation in $\bar{P}_{c}$ does not invalidate the method of calculation. Since trapping in these two areas is accomplished along the assessment lines on the same nights, environmental effects on $\bar{P}_{c}$ in the two areas should be approximately the same.

From the above it follows that

$$
D=\frac{N_{a}}{A_{c}+A_{c p}}=\frac{N_{a}}{A_{s}}
$$

Confidence intervals must be calculated for the density $(D) . N_{a}$ is assumed to be approximately equal to $N$, the real number of animals in $A_{c}+A_{c p}$. Thus $N_{a}$ does not have a confidence interval. Estimated $D_{e}$ will be in error by an amount equal to

$$
D-D_{e}=\frac{N-N_{a}}{A_{c}+A_{c p}}
$$

where $D$ equals the real density. We assume this error is negligible, and there is no known way to estimate size of the error since $P_{c}$ is not constant over time.

Both $A_{c}$ and $A_{c p}$ have confidence intervals. Normally the errors associated with the straight line could be used to place confidence interwals about a given point ( $\mathrm{S}$ te el \& T o r ri e, 1960). However, the trap stations are not picked or spaced at random and accumultive captures cannot decrease with distance, so the sampling errors associated with $\mathrm{X}$ and $\mathrm{Y}$ are biased.

If the data for each assessment line were treated separately, then there would be eight independent area estimates for $A_{c}$ and eight for $A_{c p}$. Standard errors could be calculated in the usual way (e.g.,

$$
\mathrm{S}_{\overline{\mathrm{A}}}=\sqrt{\frac{\sum \mathrm{A}_{\mathrm{c}}^{2}-\frac{\left(\Sigma \mathrm{A}_{\mathrm{c}}\right)^{2}}{\mathrm{n}}}{\mathrm{n}-1}} / \mathrm{n}
$$


with $n=8$ for the 8 assessment lines on the $16 \times 16$ grid). However, there are usually insufficient captures on single assessment lines to use this method of calculation.

Pooled data for all of the lines can also be used to calculate standard errors for the area estimates. For any one area there will be an average number of captures per station and an associated standard error; $\bar{C} \pm S_{C}$. Instead of one equation for accumulative captures versus distance in the area of no removal there would be three (Fig. 1 and 2);

$$
\begin{aligned}
& Y=a_{u}+b_{u} X, \\
& Y=a_{u}+2 S_{c}+b_{u} X, \text { and } \\
& Y=a_{u}-2 S_{-c}+b_{u} X .
\end{aligned}
$$

Graphical solution for $\bar{W}_{\mathrm{c}} \pm 2 S_{\mathrm{W}_{\mathrm{c}}}$ assuming $A_{p}=0$ is given in Fig. 2 . In $A_{c}, S_{c}$ for $a_{c}$ is 0 and there is only one equation,

$$
Y=a_{c}+b_{c} X
$$

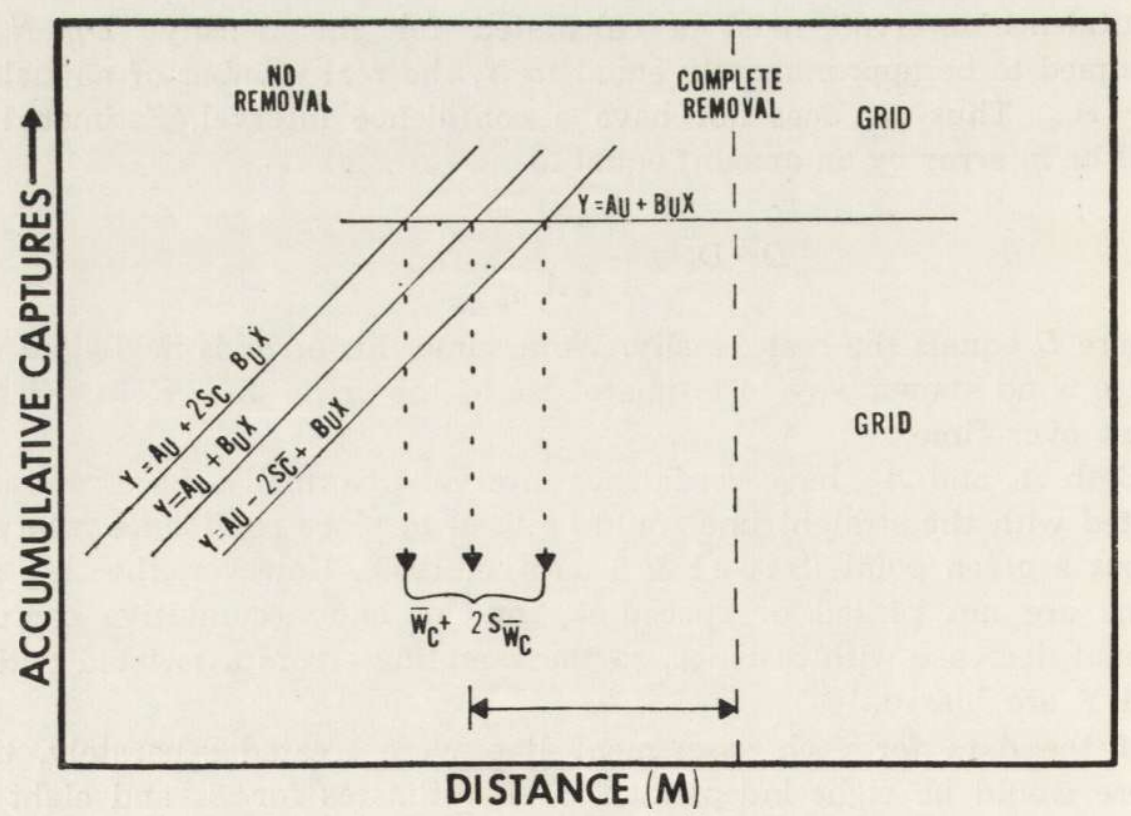

Fig. 2. The linear relationships between accumulative captures versus distance along assessment lines in an area in which the mammals were either entirely removed or not removed at all. Two standard errors for the mean number of captures per station $S_{c}$ were added or subtracted to $a_{u}$ to calculate the width of the area of complete removal $\left(W_{c}\right) . S_{c}=0$ in the area of complete removal. 
Simultaneous solution of each of the three equations taken singly with the one equation for the area of complete removal is the first step in calculating $\bar{W}_{c} \pm 2 S_{\overline{\mathrm{w}} \mathrm{c}}$. The rest of the procedure is the same as that for $W_{c}$.

\section{RESULTS}

During the first 18 days on the grid, 98 short-tailed shrews, Blarina brevicauda (S a y, 1823), 87 golden mice, Ochrotomys nuttalli (H a r1 a n, 1832), 56 Peromyscus gossypinus ( $\mathrm{L} \mathrm{e} \mathrm{C} \mathrm{o} \mathrm{n} \mathrm{t} \mathrm{e,} \mathrm{1853),} 2$ southeastern shrews, Sorex longirostris B a h ma n, 1837, 1 pine mouse, Microtus pinetorum ( $\mathrm{Le} \mathrm{Conte}, 1830$ ), 1 rice rat, Oryzomys palustris ( $\mathrm{H} \mathrm{a} \mathrm{r-}$ $\mathrm{l}$ a n, 1837), and 1 cotton rat, Sigmodon hispidus S y \& Ord, 1825 were captured (Table 2). The latter four species will not be considered separately in most of the calculations because of their low density.

\section{Assessment Line Method}

All of the animals were removed from a $49 \mathrm{~m}$ strip surrounding the grid and some were removed from areas up to $98 \mathrm{~m}$ from the grid (see assessment lines for 1 to 5 days; Figs. 3 and 4). Movement into the voided area between 12 to 15 days makes it more difficult to estimate the area of effect (Figs. 3 and 4). Using equation 5 , for 1 to 5 days the area of complete removal, $A_{c}=(225 \mathrm{~m}+49 \mathrm{~m}+49 \mathrm{~m})^{2}$ or 10.43 ha. The total area from which animals were completely or partially removed was equal to $A_{p}+A_{c}=(225 \mathrm{~m}+98 \mathrm{~m}+98 \mathrm{~m})^{2}$ or 17.72 ha. $A_{p}=$ $=7.29$ ha.

The relative area completely sampled $\left(A_{c p}\right)$ in the area of partial removal $\left(A_{p}\right)$ can be calculated using equation 8 as follows:

$$
A_{c p}=A_{p} \cdot \frac{N_{u}-N_{p}}{N_{u}-N_{c}}=7.29 \text { ha. } \frac{21.93-13.07}{21.93-8.87}=4.95 \text { ha (Fig. } 3 \text { ). }
$$

For 1 to 5 days, $2 S_{i c}$ for the area of partial removal was equal to 0.06 and for the unaffected area it was 0.23 . Using these values in equations $2 a$ and $2 b$ we can establish confidence intervals for the area estimate. The $95 \%$ confidence intervals for $A_{c p}$ fall between 4.70 and $5.01 \mathrm{ha}$. The area effectively sampled $\left(A_{s}\right)$ by the traps on the grid equal, $A_{c}+A_{c p}$ and $A_{s}=15.38$ ha with a range between 15.13 and 15.46 ha. Similar calculations for $1-15$ days gave $A_{s}=14.82$ ha and a range of 14.66 and 14.91 ha.

The difference between $A_{s(1-5)}$ and $A_{s(1-15)}$ is probably due to invasion into the voided area from days 5 to 15 (Figs. 4 \& 5). Little or no move- 
ment into the voided area occurred until days 12 to 14 (Fig. 5). There were differential capture rates for the three species on the assessment lines (Fig. 6) and on the grid (not illustrated). These differential rates make it difficult to calculate the extent of the area of effect for each species independently. By the time sufficient numbers of $O$. nuttalli and $B$. brevicauda were captured (Fig. 6) invasion into the area of removal had begun (Fig. 5). The pooled data for all species were used in the density calculations.

\section{Regression Method}

A common way to estimate population size is Hayne's regression method ( $\mathrm{H}$ a y $\mathrm{n}$ e, 1949). The resulting equation, $\mathrm{Y}=a+b X$, where $\mathrm{Y}$ equals the number of mice caught each night and $X$ equals the number previously captured, can be used to calculate the population size $\left(N_{\varrho}\right)$

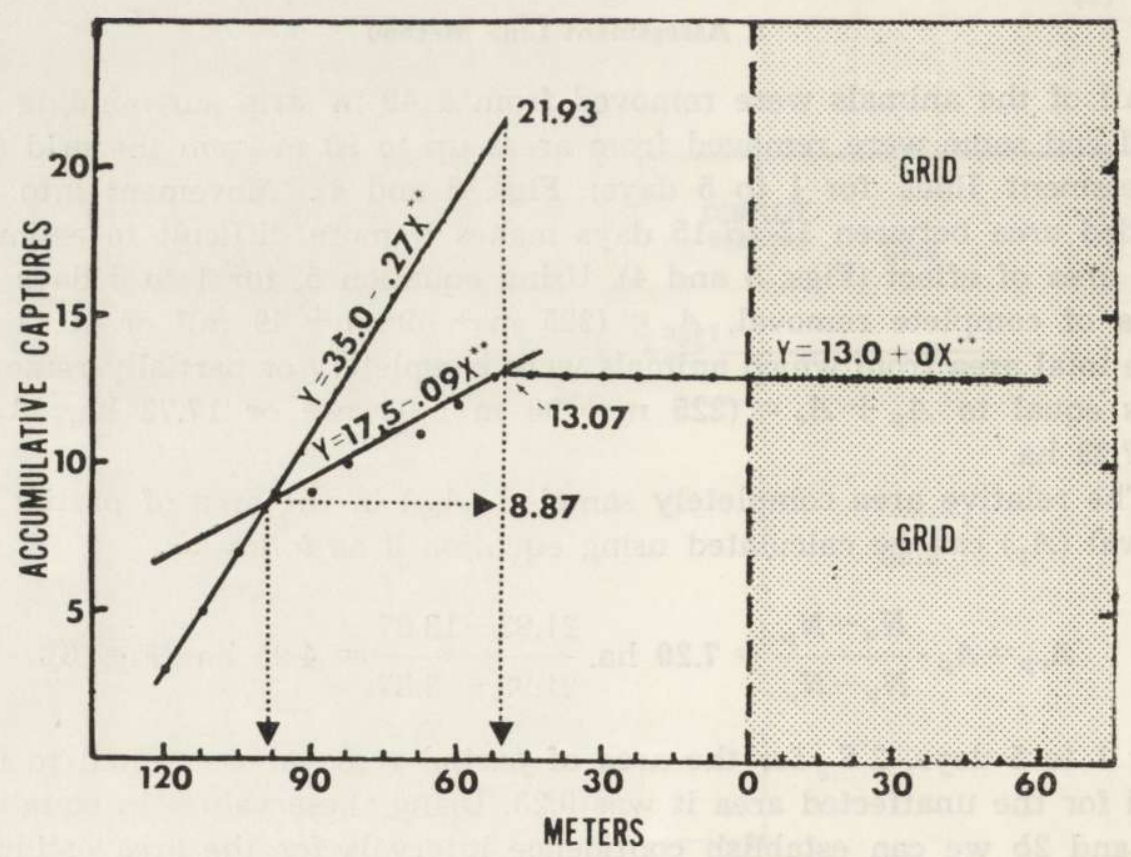

Fig. 3. Accumulative captures for the first five days of trapping on the assessment lines as a function of distance from the outer end of the assessment line to the end inside the grid. Accumulative captures should have been 21.93 animals if there were no effect beyond $49 \mathrm{~m}$ or 8.87 if there were complete removal out to $98 \mathrm{~m}$. It was calculated that accumulative captures were 13.07 animals at $49 \mathrm{~m} . * *$ Correlation coefficients $(r)$ were significant at the .01 level or $b$ was not significantly different from 0 . However, the $X$ and $Y$ variables are non random so $r$ was biased upwards. 
by setting $Y=0$ and solving the equation for $X$ (Table 2). It took nine days to get an estimate of the $O$. nuttalli population and only five days for B. brevicauda, P. gossypinus and all species combined. Population estimates $\left(N_{e}\right)$ increased with time for each species considered separately or for all species combined. Confidence intervals for each $N_{e}$ decreased with increasing time despite similar decreases in the correlation coefficient ( $r$; e.g., Fig. 7 ; see Steele \& Torrie, 1960 as the statistical reference used in this paper). Index $A$, a measure of how close the

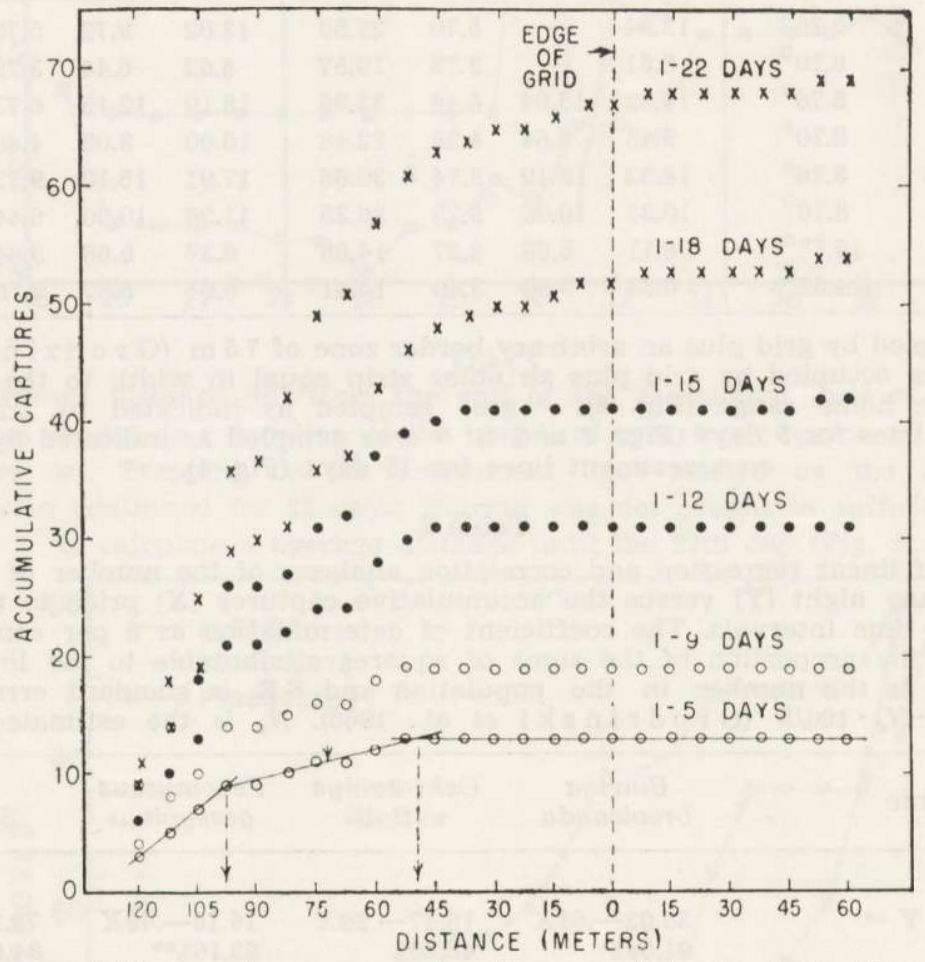

Fig. 4. Accumulative captures as a function of distance from the end of the assessment lines to the inside of the grid and the length of time the traps on the assessment lines were set.

estimate approaches the actual number caught (Grodzinski et al., 1966), averaged $5.3 \%$ (Table 2). It should be emphasized that this method seeks to calculate $N_{e}$ and not $D$. Combining this method with certain assumptions about the sampling area can result in calculation of $D$.

\section{Arbitrary Border Zone Method}

Density estimates can be obtained after the method of Grodziński et al. (1966) by dividing $N_{e}$ by the actual area of the grid plus Acta theriol. 8 
Table 1

Density estimates for each species and all species combined for various time intervals during which mammals were trapped on the grid. Densities are based upon estimated ( $\mathrm{H}$ a y n e, 1949) and actual numbers of small mammals and on areas sampled as calculated in four ways. B.b. - Blarina brevicauda, O.n. - Ochrotomys nuttalli, P.g. - Peromyscus gossypinus.

\begin{tabular}{|c|c|c|c|c|c|c|c|c|c|}
\hline \multirow{2}{*}{$\begin{array}{l}\text { Time } \\
\text { (days) }\end{array}$} & \multirow{2}{*}{$\begin{array}{l}\text { Area } \\
\text { (ha) }\end{array}$} & \multicolumn{4}{|c|}{ Estimated Number/Area(N/ha) } & \multicolumn{4}{|c|}{ Actual Number/Area(N/ha) } \\
\hline & & B.b. & O.n. & P.g. & $\begin{array}{c}\text { All } \\
\text { Species }\end{array}$ & B.b. & O.n. & P.g. & $\begin{array}{c}\text { All } \\
\text { Species }\end{array}$ \\
\hline \multirow[t]{2}{*}{$1-5$} & $5.76^{a}$ & 12.94 & - & 5.70 & 29.55 & 13.02 & 9.72 & 5.73 & 28.99 \\
\hline & $8.70^{b}$ & 8.51 & - & 3.78 & 19.57 & 8.62 & 6.44 & 3.79 & 19.20 \\
\hline \multirow[t]{2}{*}{$1-9$} & $5.76^{a}$ & 14.32 & 13.04 & 6.46 & 33.95 & 15.10 & 12.15 & 6.77 & 34.55 \\
\hline & $8.70^{b}$ & 9.48 & 8.64 & 4.28 & 22.48 & 10.00 & 8.05 & 4.48 & 22.87 \\
\hline \multirow[t]{4}{*}{$1-18$} & $5.76^{a}$ & 16.32 & 15.19 & 8.74 & 39.65 & 17.01 & 15.10 & 9.72 & 42.71 \\
\hline & $8.70^{b}$ & 10.81 & 10.05 & 5.78 & 26.25 & 11.26 & 10.00 & 6.44 & 28.27 \\
\hline & $15.38^{c}$ & 6.11 & 5.69 & 3.27 & 14.85 & 6.37 & 5.66 & 3.64 & 15.99 \\
\hline & $14.82^{d}$ & 6.34 & 5.90 & 3.40 & 15.41 & 6.61 & 5.87 & 3.78 & 16.60 \\
\hline
\end{tabular}

$a$ area occupied by grid plus an arbitrary border zone of $7.5 \mathrm{~m}$ (G rodzińs ki et al., $1966) ; b$ area occupied by grid plus an outer strip equal in width to the radius of the average home range (Fig. 8); $c$ area sampled as indicated by trapping on assessment lines for 5 days (Figs. 3 and 4 ); $d$ area sampled as indicated by trapping on assessment lines for 15 days (Fig. 4).

Table 2

Summary of linear regression and correlation analyses of the number of mammals caught on any night $(Y)$ versus the accumulative captures $(X)$ prior to that night for various time intervals. The coefficient of determination as a per cent $\left(r^{2} \cdot 100\right)$ is equal to the proportion of the sums of squares attributable to the linear relationship. $N$ is the number in the population and S.E. is standard error. Index $A=N-N_{e} \cdot 100 / N$ (G rodziński et al., 1966). $N_{e}$ is the estimated $N$.

\begin{tabular}{|c|c|c|c|c|}
\hline Time & $\begin{array}{c}\text { Blarina } \\
\text { brevicauda }\end{array}$ & $\begin{array}{l}\text { Ochrotomys } \\
\text { nuttalli }\end{array}$ & $\begin{array}{c}\text { Peromyscus } \\
\text { gossypinus }\end{array}$ & $\begin{array}{c}\text { All } \\
\text { Species }\end{array}$ \\
\hline \multicolumn{5}{|l|}{$1-5$ Days } \\
\hline Equation: $\mathbf{Y}=$ & $38.02-.51 X$ & $18.47-.26 \mathrm{X}$ & $16.10-.49 X$ & $73.20-.43 X$ \\
\hline$r^{2} \cdot 100$ & $91.09 \%$ & $48.20 \%$ & $93.16^{\% * *}$ & $84.62 \% *$ \\
\hline Estimated $N_{e}$ & 74.55 & 71.04 & 32.86 & 170.23 \\
\hline Actual $N$ & 75 & 56 & 33 & 167 \\
\hline Index $A$ & 0.6 & 21.2 & 0.4 & 1.9 \\
\hline \multicolumn{5}{|l|}{ 1-9 Days } \\
\hline Equation: $Y=$ & $35.46-.43 X$ & $18.03-.24 X$ & $14.88-.40 \mathrm{X}$ & $68.45-.35 X$ \\
\hline$r^{2} \cdot 100$ & $89.06^{\% * *}$ & $66.42 \% * *$ & $89.43 \% *$ & $86.23 \% * *$ \\
\hline Estimated $N_{e}$ & 82.47 & 75.13 & 37.20 & 195.57 \\
\hline Actual $N$ & 87 & 70 & 39 & 199 \\
\hline Index $A$ & 5.2 & 7.3 & 4.6 & 1.7 \\
\hline \multicolumn{5}{|l|}{ 1-18 Days } \\
\hline Equation: $\mathbf{Y}=$ & $31.97-.34 X$ & $16.62-.19 \mathrm{X}$ & $11.07-.22 X$ & $59.38-.26 X$ \\
\hline$r^{2} \cdot 100$ & $85.10 \%$ \%* & $66.31 \% * *$ & $62.32 \% * *$ & $80.28 \% * *$ \\
\hline Estimated $N_{e}$ & 94.03 & 87.47 & 50.32 & 228.38 \\
\hline Actual $N$ & 98 & 87 & 56 & 246 \\
\hline Index $A$ & 4.1 & 0.5 & 10.1 & 7.2 \\
\hline
\end{tabular}

* Associated $r$ value significant at the .05 level. ** Associated $r$ value significant at the .01 level. 


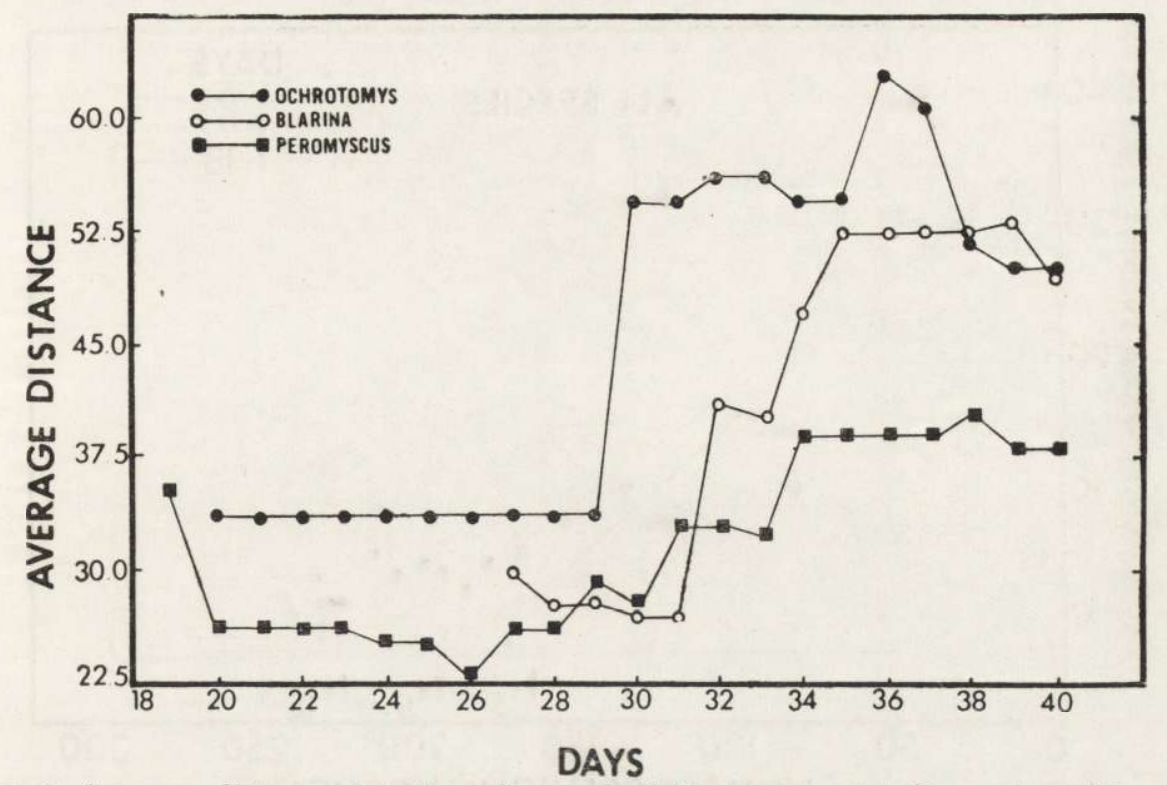

Fig. 5. Average distance $(\mathrm{m})$ from the end of the assessment lines at which each species was caught as a function of the length of time the traps on the assessment lines were set. Trapping on the assessment lines started on the 19th day of trapping and continued for 22 days. Blarina was not caught in sufficient numbers to calculate a average distance until the 27th day (Fig. 6).

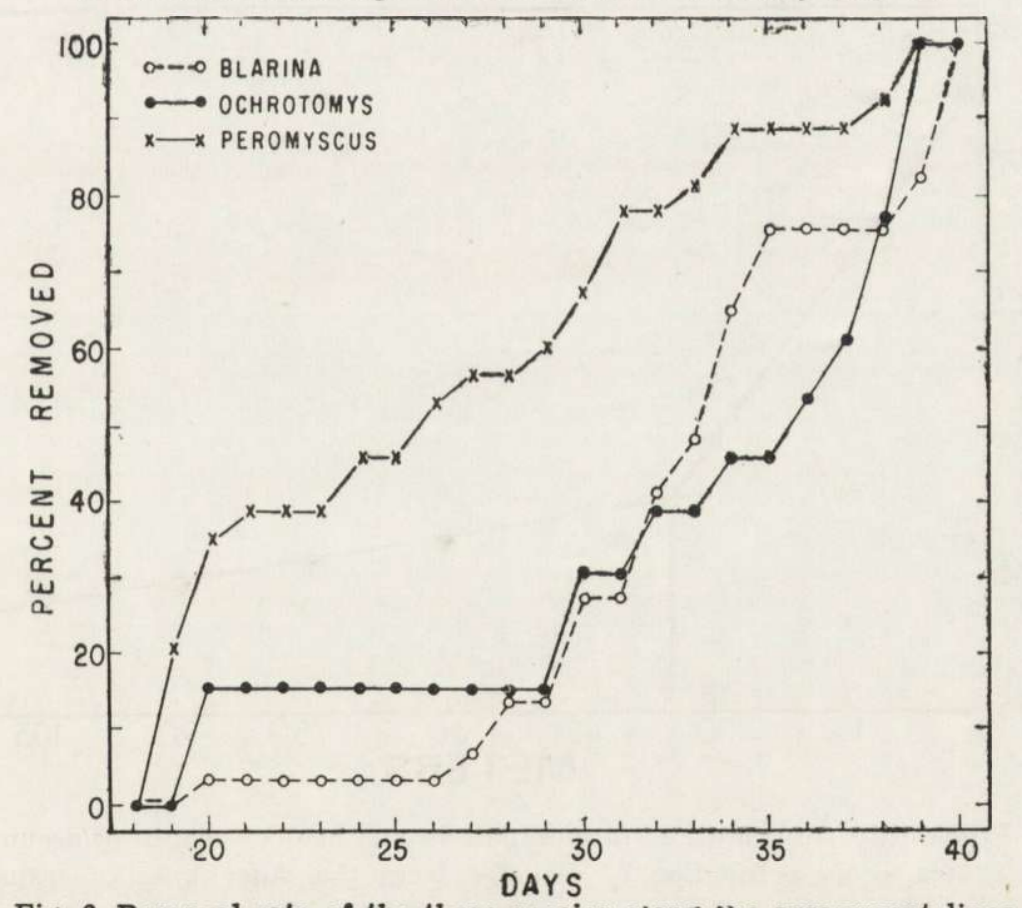

Fig. 6. Removal rate of the three species along the assessment lines. 


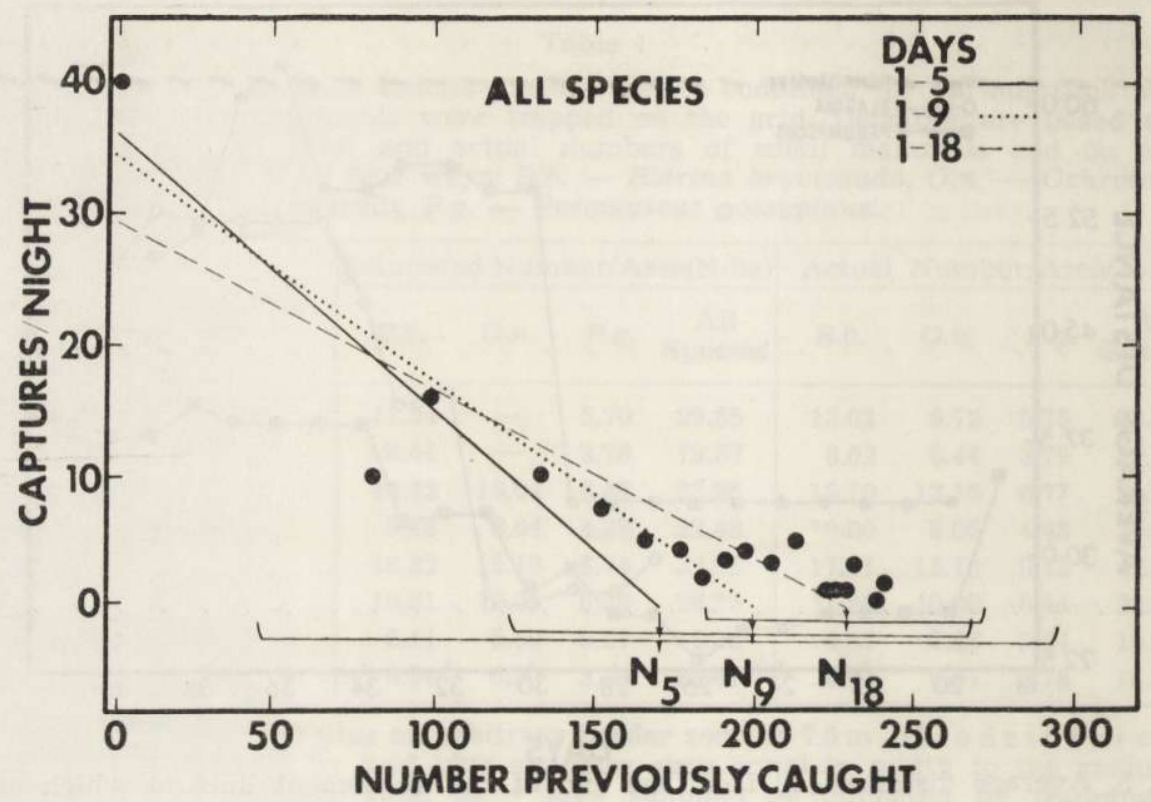

Fig. 7. Estimated population size for 5, 9, and 18 days for all species combined. Confidence limits at the .95 level are also indicated for each $N_{e}$.

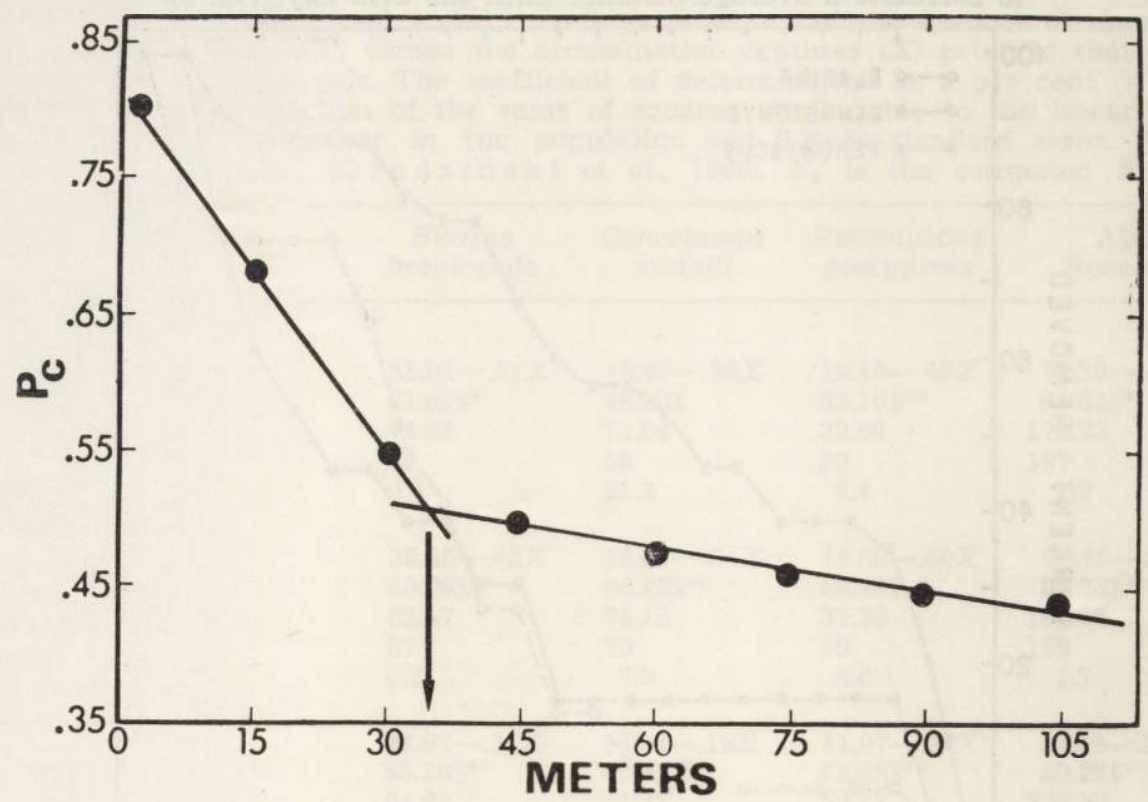

Fig. 8. Probability of capture (accumulative number of captures/accumulative number of traps) as a function of distance from the outer lines of traps $(0 \mathrm{~m})$ to the inner most lines of traps $(105 \mathrm{~m})$. 
a border of $7.5 \mathrm{~m}$ on all sides (5.76 ha or a square $240 \mathrm{~m}$ on a side; Table 1). The choice of 7.5 instead of $15 \mathrm{~m}$ or some other distance as the width of the border zone is not justified with appropriate data, but rather it represents one-half the interstation interval.

\section{Calculated Border Zone Method}

Smith, Gentry \& Golley (1970) suggested a method for estimating the sampling area around the grid occupied by animals with home ranges that partially overlap the grid. They assumed a random distribution of mammals, no immigration, a circular sphere of influence for each trap, average home range was circular, and trap spacing such that home ranges include at least several traps. Under these conditions the probability of capture $\left(P_{c}\right)$ should be at a maximum at the outer row of traps and decline to a level at which $P_{c}$ is constant. In this method, $P_{c}$ is calculated from the distribution of captures on the eight concentric squares of trap stations on the $16 \times 16$ grid. $P_{c}$ equals accumulative number of captures divided by accumulative number of traps. The number of traps and captures are accumulated from the edge toward the middle of the grid. $P_{c}$ is regressed against distance and two straight lines are calculated. Since three points are minimal for the calculation of the regression equation, the smallest grid that can be used with this method of calculation is a $12 \times 12$. The trap spacing must be such that the six data points are distributed equally into the two linear functions. Simultaneous solution of the two lines for the common $X$ point gives the average radius of the home range; this value is probably equivalent to the $r$ of $\mathrm{Hanss}$ on (1969). Confidence intervals can be calculated as in Fig. 2.

The expected decline in $P_{c}$ was observed (Fig. 8). Maximum $P_{c}$ was observed on the outer row, declining to a distance of $35 \mathrm{~m}$ (3 trap rows) and then remaining approximately constant. According to the theory, the boundary area inside the grid and outside the grid would be equal and also equal to the radius of the average home range. Since the boundary inside can be determined by the distance required to reach an equal probability of capture, it is possible to estimate the real area (A) sampled by the grid. In this study, $A=(225 \mathrm{~m}+35 \mathrm{~m}+35 \mathrm{~m})^{2}$ or $8.70 \pm .23$ ha. This value can be used instead of 5.76 ha to calculate better density estimates by dividing it into the estimated population size or into the actual number caught (Tables 1 \& 2). 


\section{Inner Square Method}

Several investigators (Pelikan, Zejda \& Holišova, 1964; Andrzejewski \& Petrusewicz, 1966; Grodzińsńi, et al., 1966; A ulak, 1967; Chełkowska \& Ryszkowski, 1968; Pelika n, 1970) have found greater number of captures per trap station on the outer rows of traps in a grid. This increase is presumably due to the capture of immigrants in the outer three rows on a $16 \times 16$ and the relatively small chance of an immigrant reaching the inner square of trap stations. A ulak (1967), Buchalczyk \& Pucek (1968), and Adamczyk \& Ryszkowski (1968) have suggested using the captures in the inner square after five days of trapping to estimate density.

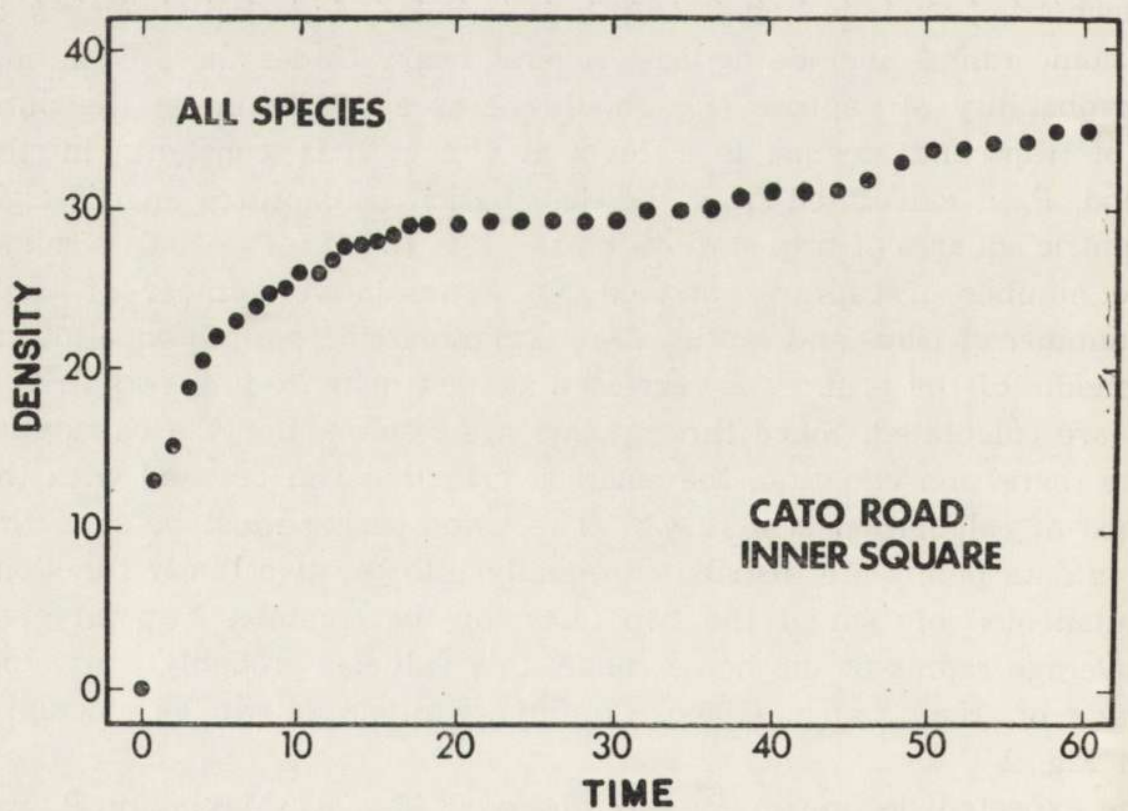

Fig. 9. Density $(N / \mathrm{ha})$ in the inner square of the $16 \times 16$ grid for all species combined as a function of time.

A larger number of captures per trap in the outer rows of the grid would be expected even if there were no immigrants because of the animals that have home ranges that only partially overlap the grid. In addition, it has not been demonstrated that immigrants do not penetrate to the center of the grid or that all of the animals in this area can be captured in five days. Density in the inner square increases as a function of time and does not begin to level off until approximately 18 days (Fig. 9). The small but steady increase in density from day 18 to day 
60 probably indicates the penetration of immigrants into the inner square. Continuation of this study for over one year revealed a similar trend (unpublished data). The rapid increase in density from day 5 to day 18 probably results from the slower removal of certain residents in this area. Slower removal of $O$. nuttalli and $B$. brevicauda than $P$. gossypinus was also observed on the grid as well as on the assessment lines (Fig. 6).

If we assume the gradual increase in density after day 18 was due entirely to immigrants (Fig. 9) and the rate of immigration was constant from day 1 on, then the regresion of density $(Y)$ against time $(X)$ for days 18 to 60 should allow a correction to be calculated for this factor. Extrapolation of the regression line back to day 1 gave approximately 26 animals/ha, which is higher than the densities calculated from the assessment lines (Table 1). Since it took only 2.8 days to remove the number of mammals equivalent to the resident population, the early immigrants must be able to penetrate the grid farther than later immigrants. Deeper penetration is probably related to greater familiarity with the grid of these early immigrants. Perhaps they should be called shifting residents because their normal movement patterns would include much of the grid ( $\mathrm{F}$ a u s $\mathrm{t}$ et al., 1971). There is also no evidence to indicate that these animals moved into the voided area of the grid because of the removal of animals on the grid. They probably would have been caught on the grid as a part of their normal activity.

\section{DISCUSSION}

Which of the many techniques results in the best density estimates? The answer to this question is still not an absolute one since the real density is not known. However, the assessment line method seems to account for more of the data and rest on fewer assumptions than the other methods. The fit of the data to the mathematical model was also quite good (Fig. 3). Of course, an alternate explanation of the assessment line data could result in a different evaluation of the best technique for estimating density. Habitat heterogeneity could result in changes in the rate of capture as a function of distance, but it is difficult to understand how an area of no captures could fortuitously extend out to $49 \mathrm{~m}$ from the grid and the captures all of a sudden increase at a constant rate out to $98 \mathrm{~m}$ without an apparent change in habitat.

There are three major criticisms of the assessment line technique as employed by us. The first and most damaging is that $P_{c}$ in $A_{u}$ and $A_{c p}$ may not be equal during the time in which the traps on the assessment lines are operated. If $\bar{P}_{c}$ were greater in $A_{u}$ than in $A_{c p}, N_{e}$ would be 
greater than $N$; the converse would also be true. If the later removal of certain animals (e.g. Fig. 6) is due to the inhibitory effects of other animals that must be removed before they can be captured $(\mathrm{C}$ a $1 \mathrm{~h}$ o u n, 1963) then the first criticism is probably justified. In $A_{c p}$ the dominant animals would have been removed but not in $A_{u}$; subordinate animals would be caught along the assessment lines in $A_{c p}$ and dominants in $A_{u}$. On the other hand, if trap response is independent of density and determined by neophilic and neophobic reactions (F a ust, et al., 1971) the first criticism is unjustified. Research is needed to evaluate this point.

The second criticism is that mortality during long sampling intervals would influence the estimates of the areas of effect. For example, extensions of $A_{c}$ would occur if animals residing on the border between $A_{c p}$ and $A_{c}$ died during the sampling interval. The effect of mortality could be reduced by decreasing the sampling interval, but then it would not be possible to capture a significant portion of the resident animals in the sampling area (e.g. Figs. 6 \& 9). The Polish recommendation of five days of removal can result in an entirely erroneous picture of the mammal community (Gentry, et al. 1968; Faust et al. 1971; $\mathrm{K}$ a ufman, et al. 1971). Another approach might be to develop techniques to measure the magnitude of mortality. Another set of assessment lines in an adjacent area could be used to determine the ambient rate of capture as a function of distance at the beginning of the sampling interval. Differences in this rate on the two sets of assessment lines in $A_{u}$ might be used to calculate mortality during the sampling interval. If some factor is thought to be important, an attempt must be made to directly measure it if possible. Increased precision in estimating $D$ will require considerably more effort.

Density can become so low that the assessment line technique will not work because the fit of the data to the linear model would not be statistically significant and/or the slope would not be different from zero. Low density populations would probably also present problems for the other techniques. Either the assumptions for the models would not be met or the confidence intervals would be extremely large so as to make the density estimate almost worthless.

Other miscellaneous comments on the assessment line method should be mentioned. Assessment lines must be long enough to extend into $A_{u}$ with at least six stations in $A_{u}$. In nur case there were only four stations in this area. We obviously did not anticipate such a large area of effect. Accumulation of captures over distance along a trapping line should result in a straight line in $A_{u}$ but does not necessarily in $A_{c p}$. Data from $A_{c p}$ may be fit to other types of functions and calculations 
modified accordingly. Assessment lines must be far enough apart that they do not interact. A better arrangement than the one used in this study would be one line perpendicular to each side of the grid and one extending from each corner. This would also allow evaluation of the area of effect around the corners of the grid rather than assume a rectangular area of effect as we did in our calculations. Stations on the assessment lines should not be located at the same site as those on the grid unless you want to evaluate the effect of new versus old stations. Under no circumstances should more than one-half of the assessment line stations within the grid be located at old grid stations, since all of the stations on the outer parts of the assessment lines are new in that there have been no baited traps there previous to the first day of trapping on the assessment lines. Prebaiting on the grid is unnecessary and not desirable. The primary function of prebaiting was to secure a good fit of the data for the liner regression method of $\mathrm{H}$ a y $\mathrm{ne}$ (1949). If trapping can be used to study spatial patterns and social relationships, prebaiting surely modifies the data in respect to these two phenomenon and serves no essential function in the assessment line method.

It is also important to understand the reasons for the failure of the other techniques to result in reliable density estimates. Hayne's regresion method or some modification of it is central to most of the other techniques. As long as captures continue to decrease in a regular manner, it is assumed that you are sampling only the resident population. In our study this would include the first eight days of removal trapping (Fig. 7). As previously mentioned, a number of animals equivalent to the residents on the grid were removed by 2.8 days. Some of the animals living on the periphery of the grid must have the same $P_{c}$ as the residents. If the peripheral animals continued to distribute their activity on and off the grid their $P_{c}$ should be lower than that of the residents; prebaiting must shift the focal points of activity for these animals onto the grid (B a bińska \& Bock, 1969). Thus even if the data fit Hayne's regression model, the estimate will be higher than the number of animals present prior to prebaiting.

Of course there is the question of whether the data do fit the model. The correlation coefficient $(r)$ is one indicator of the mathcmatical fi: of the data points to the straight line. The statistic $r$ is seldom given although the results cannot be evaluated without it (e.g. Grodzin$\mathrm{ski}$ et al., 1966), and if it is not significant at some desired level (usually $P=.05$ ) the population estimate should not be given because use of the model is not justified. Degrees of freedom $(d f)$ equals the number of trapping nights minus two. In the case of the Polish re- 
commendation of five trapping nights, $d f$ equal three and $r$ must equal or exceed .878 at the .05 level of significance. Large variations in $P_{c}$ for given species over the first few nights means that no population estimate can be obtained (e.g. Gentry et al., 1968). Hayne (1949) did not give $r$ values in his original paper and our recalculations of his data indicate a nonsignificant fit of his data to his model for the example. Even if $r$ is significant the fit may not be significant since the $X$ variable is accumulated captures and thus is not strictly a random variable and calculations result in an $r$ that is biased to the high side (A cton, 1966). We are currently exploring other methods of calculation for $r$.

Confidence intervals for $N_{e}$ are seldom given. Both the confidence intervals (Fig. 7) and the necesary $r$ value for significance decreases with an increase in $d f$ or the length of the sampling interval. Confidence in results obtained from five days of trapping can seldom be high. Another method of calculating $N_{e}$ developed by J an ion et al. (1968) does not even give a satisfactory way to test the fit of the data to their proposed model. Methods of calculating $N$ and the techniques of data presentation must allow the reader to evaluate the degree of statistical confidence justified by the results.

The population estimate from $\mathrm{H}$ ay ne's method must be divided by an area to obtain density. Some form of the arbitrary border zone method is normally used. We can no longer guess at the width of the border zone, and assume it is usually quite narrow since it obviously is not.

The inner square method overestimates density because of the prebaiting effect and the penetration of certain nonresident animals to the inner square. This penetration is so extensive that the calculated border zone method is also not valid, and the results in Fig. 8 are more a function of the removal pattern of animals not resident on the grid rather than the spatial distribution of the residents. The calculated border zone method should be appropriate for data from short term catch-mark-release studies not involving prebaiting.

One criticism that might be leveled at this paper is that the results do not generally apply to mammal populations in other habitats and regions of the world. While complete generality is probably too much to expect, assuming our conclusions only apply to a few species in the lowland-mesic hardwood forest would be a mistake. Small mammals are much more mobile than previously recognized (F a u s t et al. 1971), and our experience now includes a variety of habitats (e.g., chaparral, desert scrub and pine forest; unpublished results). Density is crucial to many other calculations for ecological systems analysis and has two 
equally important components, number and area, that must be estimated in future IBP field studies with mammals. Movement of the mammals during the sampling period makes estimation of the area more difficult and causes large errors in estimates made without taking movement into account.

\section{REFERENCES}

1. A cton F. S., 1966: Analysis of straight-line data. Dover Publications: 1-267. New York.

2. A damczyk K. \& Ryszkowski L., 1968: Estimation of the density of a rodent population using stained bait. Acta theriol., 13: 295-311.

3. A u lak W., 1967: Estimation of small mammal density in three forest biotopes. Ekol. pol., A, 15: 755-778.

4. Babińska J. \& Bock E., 1969: The effect of prebaiting on captures of rodents. Acta theriol., 14: 267-270.

5. Buchalczyk T. \& Pucek Z., 1968: Estimation of the numbers of Microtus oeconomus using the Standard Minimum Method. Acta theriol., 13. 461-482.

6. Calhoun J. B., 1963: The social use of space. [In: „Physiological Mammalogy« Eds. Mayer W. \& Van Gelder R.] Academic Press: Vol. 1: 1-187. Ne'w York.

7. Chełkowska H. \& Ryszkowski L., 1967: Causes of higher abundance estimates of small rodents at the edges of sampling area in forest ecosystems. Ekol. pol. A, 15: 737-746.

8. Faust B. F., Smith M. H. \& Wray W. B., 1971: Distance moved by small mammals as an apparent function of grid size. Acta theriol. 16: 161-177.

9. Gentry J. B., Golley F. B. \& Smith M. H., 1968: An evaluation of the proposed International Biological Program census method for estimating small mammal populations. Acta theriol., 13: 313-327.

10. Gentry J. B., Golley F. B. \& Smith M. H., 1971a: Yearly fluctuations in small mammal populations in a southeastern United States hardwood forest. Acta theriol. 16: 179-190.

11. Gentry J. B., Smith M. H. \& Beyers R. J., 1971b: Use of radioactive isotopes to study movement patterns in small mammals populations. Ann. Zool. Fennici, 8: 17-21.

12. Gentry J. B., Smith M. H. \& Chelton J. G., 1971c: An evaluation of the octagon census method for estimating small mammal populations. Acta theriol. 16: 149-159.

13. Grodziński W., Pucek Z. \& Ryszkowski L., 1966: Estimation of rodent numbers by means of prebaiting and intensive removal. Acta theriol. 11: $297-314$.

14. Hanson W. R., 1967: Estimating the density of an animal population. J. Res. Lepidoptera 6: 203-247.

15. Hans on L., 1969: Home range, population structure and density estimates at removal catches with edge effects. Acta theriol. 14: 153-160.

16. Hayne D. W., 1949: Two methods for estimating population from trapping records. J. Mamm. 30: 399—411. 
17. Kaufman D. W., Smith G. C., Jones R. M., Gentry J. B. \& Smith M. H., 1971: Use of assessment lines to estimate density of small mammals. Acta theriol. 16: 127-147.

18. Janion M., Ryszkowski L. \& Wierzbowska T., 1968: Estimate of numbers of rodents with variable probability of capture. Acta theriol. 13: 285-293.

19. Pelikan J., Zejda J., Holišova V., 1964: On the question of investigating small mammal populations by the quadrate method. Acta theriol. 9: $1-24$.

20. Pelikan J., 1970: Testing and elimination of the edge effect in trapping small mammals. [In "Energy flow through small mammal populations Eds. K. Petrusewicz \& L. Ryszkowski]. Polish Sci. Publ.: 57-62. Warszawa.

21. Ryszkowski L., Andrzejewski R. \& Petrusewicz K., 1968: Comparison of estimates of numbers obtained by the methods of release of marked individuals and complete removal of rodents. Acta theriol. 12: $329-341$.

22. Smith M. H., 1968: A comparison of different methods of capturing and estimating numbers of mice. J. Mamm. 49: 455-462.

23. Smith M. H., Gentry J. B. \& Golley F. B., 1970: A preliminary report on the examination of small mammal census methods. [In: "Energy flow through small mammal populations" Eds. K. Petrusewicz \& L. Ryszk ow s k i]. Polish Sci. Publ.: 25-29. Warszawa.

24. St e el R. G. D. \& Torrie J. H., 1960: Principles and procedures of statistics. McGraw-Hill Book Company: 1-481. New York.

25. T a n a k a R. \& K a n a mori M., 1967: New regression formula to estimate the whole population for recapture-addicted small mammals. Res. Popul. Ecol. 9: 83-94.

26. Tanton M. T., 1965: Problems of live trapping and population estimation for the wood mouse, Apodemus sylvaticus (L.). J. Anim. Ecol. 34: 1-22.

27. T a nton M. T., 1969: The estimation and biology of populations of the bank vole (Clethrionomys glareolus (Schr.) and wood mouse (Apodemus sylvaticus (L.)). J. Anim. Ecol. 38: 511-529.

28. Wheeler G. G. \& Calhoun J. B., 1968: Manual for conducting ICSM census category 04. (octagon census and assessment traplines). ICSM manual series No. 4, Parts 1 and 2, Ed. 1: $1-50$.

Accepted, March 28, 1971.

Savannah River Ecology Laboratory SROO, Box A

Department of Zoology and Institute of Ecology

Aiken, South Carolina 29801 USA

University of Georgia

Athens, Georgia, USA 30601 
Michael H. SMITH, Ronald BLESSING, John G. CHELTON, John B. GENTRY, Frank B. GOLLEY i John T. McGINNIS

\section{OKRESLENIE ZAGĘSZCZENIA POPULACJI DROBNYCH SSAKÓW PRZY UŻYCIU DZIAŁKI ODŁOWNEJ I TRANSEKTÓW}

\section{Streszczenie}

Do określenia wskaźnika zagęszczenia użyto zmodyfikowanej polskiej metody Standard Minimum. Oceny zasięgu wyłowu na działce dokonano przy pomocy pułapek ustawionych na 8 transektach.

W ciągu początkowych 18 dni odłowiono na działce 98 osobników Blarina brevicauda, 56 Peromyscus gossypinus, 87 Ochrytomys nuttalli oraz 5 osobników małych ssaków, należących do innych gatunków (Tabela 2). Teoretyczne rozważania nad obliczaniem zagęszczenia przy użyciu transektów przedstawiono na przykładzie (Fig. 1-4). Zagęszczenie określone przy pomocy różnych metod przedstawiono w Tabeli 1. Dane uzyskane z transektów (Fig. 3) ujawniły, że ssaki łowią się aż $98 \mathrm{~m}$ spoza działki. Zagęszczenie obliczone sposobem polecanym w polskiej metodzie Standard Minimum było o $81 \%$ wyższe niż porównywalne dane (15.99 małych ssaków na ha) uzyskane za pomocą metody transektów (Tabela 1). Tempo wyłowu było charakterystyczne dla poszczególnych gatunków i to zarówno na działce, jak i na transektach (Fig. 6). Pomiędzy 12 a 14 dniem wyłowu na transektach stwierdzono wzrost ruchliwości małych ssaków w kierunku opróżnionej powierzchni działki. Oznaczana wielkość populacji wzrasta z czasem, ale maleja granice przedziału ufności (Fig. 7). Zagęszczenie liczone metodą wewnętrznych kwadratów również wzrasta z czasem (Fig. 9). Wszystkie metody oceny efektu krawędzi (porównaj Fig. 8) dają wartości zaniżone w porównaniu do metody transektów. Jedynie ten ostatni sposób daje właściwe oznaczenie przedziałów ufności wielkości strefy zewnętrznej. Przyszłe badania winny oszacować wielkość powierzchni oddziaływania działki, co umożliwi sprawdzenie rzetelności oznaczeń zagęszczenia populacji ssaków. 